\title{
Characterisation of shrimp haemocytes and plasma components by
} \section{monoclonal antibodies}

\author{
J. Rodriguez ${ }^{1}$, V. Boulo², E. Mialhe ${ }^{1}$ and E. Bachere ${ }^{2, *}$ \\ ${ }^{1}$ CENAIM-ESPOL, PO Box 4519, Guayaquil, Ecuador \\ 2Défense et Résistance chez les Invertébrés Marins (DRIM), IFREMER-CNRS-Université de Montpellier 2, Case courrier 80, 2 \\ Place Eugène Bataillon, F-34095 Montpellier cedex 05, France \\ ${ }^{*}$ Author for correspondence
}

\section{SUMMARY}

Various haemolymph components of the shrimp Penaeus japonicus were identified and characterised by monoclonal antibodies. Three groups of monoclonal antibodies were raised. Their reactivity to haemocyte types and/or secreted molecules was determined by immunofluorescence and the molecular masses of the antigens were analysed by westernblotting. A $170 \mathrm{kDa}$ protein, in reducing conditions, was recognized by four panhaemocytic monoclonal antibodies from group 1. This protein was present both in the plasma and in the haemocytes from which it appears to be secreted. The shrimp haemocytes were separated by isopycnic centrifugation on a Percoll gradient and the different subpopulations were antigenically analysed using the two monoclonal antibodies, 40E2-2A and 40E10-2B, from group 2. The granular cells were labelled by $40 \mathrm{E} 2-2 \mathrm{~A}$ which was specific for a protein of $142 \mathrm{kDa}$ also present in plasma. By comparison, the 40E10-2B monoclonal antibody was assumed to be the marker for small hyaline and semigranular cells since the granular ones were not labelled.
Moreover, the antigen immunoprecipitated by this monoclonal antibody was shown to have different molecular masses of 250, 150, 66 and $27 \mathrm{kDa}$ under nonreducing conditions. It appeared to be secreted by the haemocytes. Some plasma proteins were recognized by the third group of monoclonal antibodies. The antibodies, designated 41D113A, 42C11-3B and 42E8-3C, all immunoprecipitated a protein with an apparent molecular mass of $180 \mathrm{kDa}$ under reduced conditions. The 44E6-3D antibody was specific for a $75 \mathrm{kDa}$ protein under reduced conditions and was shown to be immunoreactive against $P$. japonicus haemocyanin extract. An antigenic relationship was studied for the haemolymph components of $P$. japonicus and two other shrimp species, $P$. vannamei and $P$. indicus. Hypotheses about the possible nature of the proteins, antigenically identified, are advanced.

Key words: crustacea, shrimp haemolymph, monoclonal antibody, haemocyte subpopulation, plasma protein, haemocyanin, immunity

\section{INTRODUCTION}

Research in crustacean immunology has been essentially focused on crayfish, and in particular those processes known to be mediated by haemocytes: phagocytosis, encapsulation, melanisation and coagulation. The immune reactions are beginning to be understood, especially those linked to the prophenol oxidase activating system and associated recognition factors, through the isolation and characterisation of numerous components of this system (Söderhäll and Cerenius, 1992).

In comparison, the present knowledge of the immune system of penaeid crustaceans is limited, but research is currently expanding because of the economic importance of shrimp aquaculture throughout the world and the significant impact of infectious diseases (Lightner, 1983). Noninfectious diseases are also now being studied in relation to marine pollution caused by pesticides. It has become crucial to better understand the immune processes, in terms of basic research and also for disease prevention. Diseases could be prevented by regularly monitoring the immune state of the shrimps in the farms to detect as early as possible any abnormal conditions, by performing immunostimulation to prevent infection, or by selecting shrimp strains with increased immune capability. For these purposes, however, it is first necessary to characterise immune cells and secreted molecules, and then to study the immune mechanisms at the cellular and molecular levels.

The haemocytes of Penaeus japonicus have been characterised on the basis of ultrastructural features (Tsing et al., 1989). The following three cell types have been recognized: haemocytes with small granules, haemocytes with large granules and undifferenciated haemocytes. By combining the results from morphological and cytochemical analyses, two cell lineages have been determined for the haemocytes of Sicyonia ingentis. One lineage is characterised by granular deposited material and corresponds to agranular and striated granular haemocytes that are associated with haemolymph coagulation. The other lineage corresponds to granular cells that are related to the prophenol oxidase system (Hose et al., 1987; Hose and Martin, 1989). Concerning humoral factors, a 
lectin, monodin, and an agglutinin have been purified and characterised, respectively, from the haemolymph of $P$. monodon and P. californiensis (Ratanapo and Chulavatnatol, 1990; Vargas-Albores et al., 1993).

In order to study further immune cellular and humoral effectors in shrimp, monoclonal antibodies (mAbs) have been prepared for $P$. japonicus using hybridoma technology (Kölher and Milstein, 1975). The paper describes the production and the use of a panel of ten cloned haemolymph-specific hybridomas. Various components of haemolymph were discriminated by these mAbs which were first analysed by immunofluorescence on haemolymph samples. Then primary cultures were prepared in several ways in order to determine the $\mathrm{mAb}$ reactivity against haemocyte types and/or secreted molecules and their ability to discriminate haemocyte subpopulations. The molecular masses of the antigens were determined by western blot analyses or by electrophoresis of immunoprecipitates. The antigenic relationship between the haemolymphs of $P$. japonicus and of two other economically important shrimp species, $P$. vanname $i$ and $P$. indicus, was then investigated.

\section{MATERIALS AND METHODS}

\section{Animals and haemolymph collection}

For all experiments, juvenile male and female shrimps were used from the species Penaeus japonicus, the Kuruma prawn, P. indicus, the Indian white prawn and $P$. vannamei, the white leg shrimp.

The $P$. japonicus and $P$. indicus shrimps were maintained in the laboratory in $500-1$ tanks $\left(17^{\circ} \mathrm{C}\right)$ equiped with air-lift circulating sea water. $P$. vannamei haemolymph samples were prepared in Ecuador (CENAIM, ESPOL, San Pedro). Only animals in the intermoult stage, at about $15-20 \mathrm{~g}$, were used in the experiments.

Haemolymph was obtained from the ventral sinus located at the base of the first abdominal segment. The samples were collected using a $23 \mathrm{G}$ gauge syringe and immediately half diluted with $1 \mathrm{ml}$ of precooled $\left(4^{\circ} \mathrm{C}\right)$ modified Alsever solution (AS) $(27 \mathrm{mM}$ Na citrate, $336 \mathrm{mM} \mathrm{NaCl}, 115 \mathrm{mM}$ glucose, $9 \mathrm{mM}$ EDTA, pH 7) used as anticoagulant, which also prevents melanization and keeps haemocytes in a quiescent state.

\section{Haemocyte preparations}

The different haemocyte preparations were either used for immunocytochemical labelling or stained with Hemacolor kit (Merck).

\section{Adherent primary cultures}

The haemolymph collected in $\mathrm{AS}, \mathrm{pH} \mathrm{7,} \mathrm{was} \mathrm{used} \mathrm{for} \mathrm{primary}$ cultures, either directly or after washing from plasma components by centrifugation $\left(700 \mathrm{~g}, 10\right.$ minutes, $4^{\circ} \mathrm{C}$ ) with $\mathrm{AS}, \mathrm{pH} 7$ or $\mathrm{pH}$ 4.6. To avoid cell disruption and degranulation (Söderhäll and Smith, 1983), the cells were washed with $\mathrm{AS}, \mathrm{pH}$ 4.6. To restore haemocyte adherence and spreading capability, haemocytes were resuspended in sterile saline solution (SSS) $\left(15 \mathrm{mM} \mathrm{CaCl}_{2}, 7 \mathrm{mM} \mathrm{KCl}, 12.5 \mathrm{mM}\right.$ $\mathrm{MgCl}_{2} \cdot 6 \mathrm{H}_{2} \mathrm{O}, 7.4 \mathrm{mM} \mathrm{NaHCO} 3,336 \mathrm{mM} \mathrm{NaCl}_{2}, \mathrm{pH}$ 7; La Peyre and Chu, 1990) and $50 \mu \mathrm{l}$ suspension drops were layered on microprint slides. Haemocytes were allowed to adhere to the surface for 2 hours before gentle washing with SSS.

\section{Primary cultures in suspension}

After washing, haemocytes were resuspended and incubated in microtubes for 1 or 2 hours in SSS then used for preparing haemocyte extracts.

\section{Cytocentrifugation}

Haemocytes collected in AS were fixed by adding 4\% formalin (30 minutes), spun, washed twice and resuspended in AS. Approximately $2 \times 10^{5}$ haemocytes were then cytocentrifuged (Cytotek-centrifuge, Miles) per microscope slide ( $200 \mathrm{~g}, 5$ minutes).

\section{Haemocyte separation procedure}

Shrimp haemocyte subpopulations were separated by isopycnic centrifugation in a discontinuous Percoll gradient according to the protocol used for molluscan haemocytes (Bachère et al., 1988). Briefly, the haemocyte suspension in $\mathrm{AS}, \mathrm{pH} 4.6$, was layered onto Percoll gradient consisting of $1.5 \mathrm{ml}$ fractions of $10 \%, 20 \%, 30 \%$, 40\%, 50\%, 60\% and 70\% Percoll (Pharmacia) in AS, pH 7. After 30 minutes centrifugation at $200 \mathrm{~g}\left(4^{\circ} \mathrm{C}\right)$, the cells banding at the different interfaces were collected, washed from Percoll by centrifugation through a $10 \%$ sucrose cushion $\left(500 \mathrm{~g}, 15\right.$ minutes, $\left.4^{\circ} \mathrm{C}\right)$ then resuspended in AS, $\mathrm{pH}$ 4.6. The haemocytes were then prepared either for primary cultures or cytocentrifugation.

\section{Production of monoclonal antibodies}

For immunization, the haemolymph/AS mixtures were made isoosmotic to mice serum by dilution with sterile distilled water and then subjected to a freeze-thaw cycle. Two Balb/c mice were immunized by intraperitoneal injection of $500 \mu \mathrm{l}$ antigen suspension $\left(2 \times 10^{6}\right.$ haemocytes), followed by two subsequent injections at weekly intervals. Serum titers were estimated 13 days after the last booster by indirect immunofluorescence assay (IIFA) as described below. The selected mouse presenting the highest antibody titer was reinjected 3 days before lymphocyte hybridization.

Spleen from selected mice was dissected and fused with P3-X63Ag8-653 myeloma using polyethylene glycol as fusogen, as described by French et al. (1986). Hybridomas were selected in RPMI 1640 medium (Gibco Ltd) supplemented with $15 \%$ foetal calf serum, $2 \mathrm{mM}$ L-glutamine, $0.1 \mathrm{mM}$ hypoxanthine, $0.4 \times 10^{-3} \mathrm{mM}$ aminopterine and $0.016 \mathrm{mM}$ thymidine. Screening of hybridomas secreting specific antibodies was performed by indirect immunofluorescence assay (IIFA) on haemocyte primary cultures prepared with whole haemolymph in microplates. The cells were formalin fixed. Hybridomas giving positive results were subcloned by limited dilution with 0.3 cells distributed per well, then tested again for their specificity by IIFA.

\section{Indirect immunofluorescence assay (IIFA)}

The haemocyte preparations, either primary cultures or cytocentrifugated cells, were fixed and permeabilized with acetone for 5 minutes. Slides were overlaid with $50 \mu \mathrm{l}$ specific antibody hybridoma culture medium and incubated for 30 minutes at room temperature (RT) in a moisture chamber. After three washings with immunofluorescence buffer (IF; Diagnostics Pasteur), the cells were incubated for 30 minutes (at RT) in the dark with FITC-conjugated goat anti-mouse Ig serum diluted at 1:1000 in IF buffer containing 1\% Evans Blue. Finally, the slides were washed three times and mounted in buffered glycerin for observation by epifluorescence.

\section{Isotyping of monoclonal antibodies}

The monoclonal antibodies were isotyped using the Ouchterlony immunodiffusion method with a 'Mouse monoclonal typing kit' (ICN ImmunoBiologicals) and following the manufacturer's instructions.

\section{Dot blotting and western blotting}

The library of monoclonal antibodies was first assayed by dot blots against plasma and haemocytic extract samples compared under conditions where proteins were either native or reduced in the presence of $2 \%$ SDS and $100 \mathrm{mM}$ dithiothreitol. The mAbs were also tested against samples of haemocyanin. The respiratory pigment purified from $P$. japonicus haemolymph was kindly supplied by Dr Yen-Lin Song (Taïwan).

Haemolymph was collected in $\mathrm{AS}, \mathrm{pH} 7$; the haemocytes were pelleted and the supernatant was kept at $-20^{\circ} \mathrm{C}$ as plasma. The haemo- 
cytes were washed twice with $\mathrm{AS}, \mathrm{pH} 4.6$, and finally resuspended in single detergent lysis buffer (50 mM Tris- $\mathrm{HCl}, \mathrm{pH} 8,150 \mathrm{mM} \mathrm{NaCl}$, $0.02 \% \mathrm{NaNO}_{3}, 100 \mu \mathrm{g} / \mathrm{ml}$ PMSF, $1 \mu \mathrm{g} / \mathrm{ml}$ aprotinin, $1 \%$ Triton $\mathrm{X}-$ $100)$ according to Sambrook et al. (1989). After 30 minutes of incubation on ice, cell debris was removed by centrifugation (9000 $\mathrm{g}, 5$ minutes) and the supernatant kept at $-20^{\circ} \mathrm{C}$ until used.

The different samples of plasma and haemocyte lysate, both native and denaturated, were applied to Hybond nitrocellulose paper (Amersham International Ltd.) using a dot-blot apparatus (Biodot, Bio-Rad). For western blotting, the samples were run on SDS-polyacrylamide gels (SDS-PAGE) using the PhastSystem apparatus (Pharmacia) under reducing and non reducing conditions. The proteins were then electrotransferred onto nitrocellulose Hybond or nylon membrane (Millipore) at $5 \mathrm{~V} / \mathrm{h}$ for 15 minutes in $25 \mathrm{mM}$ Tris$\mathrm{HCl}$ buffer containing $192 \mathrm{mM}$ glycine and $20 \%$ methanol, $\mathrm{pH}$ 8.3.

For labelling with antibodies, dot-blot or western blot membranes were incubated for 1 hour at RT, in blocking solution consisting of $20 \%$ gelatine hydrolysate in PBS. After three washings in PBS with $1 \%$ Tween-20, the hybridoma culture media were incubated overnight at $4{ }^{\circ} \mathrm{C}$ with agitation. The membranes were washed three times in PBS-1\% Tween-20 then incubated (1 hour, RT) with goat anti-mouse whole IgG molecules conjugated to alkaline phosphatase (Biosys) prepared in PBS with 5\% gelatine hydrolysate. After three washes, the membranes were then incubated in substrate solution $(0.016 \%$ (w/v) 5-bromo-4-chloro-3-indolyl phosphate, $0.033 \%$ (w/v) Nitro Blue Tetrazolium in $100 \mathrm{mM} \mathrm{NaCl}, 5 \mathrm{mM} \mathrm{MgCl}, 100 \mathrm{mM}$ Tris- $\mathrm{HCl}$, $\mathrm{pH}$ 9.5) for 10 minutes at RT. Reactions were stopped with $2 \mathrm{mM}$ EDTA in PBS.

\section{Immunoprecipitations}

Plasma or haemocyte lysate samples were dialysed or diluted with buffer (NET gel buffer: $0.1 \%$ Triton X-100, $150 \mathrm{mM} \mathrm{NaCl}, 5 \mathrm{mM}$ EDTA and $50 \mathrm{mM}$ Tris-HCl, $\mathrm{pH} 7$ ). The antibodies, either purified or as hybridoma culture medium, were added and incubated under agitation for 1 hour at $4^{\circ} \mathrm{C}$. Then, $30 \mu$ Protein A-Sepharose CL-4B beads (Pharmacia) were added and incubated for 1 hour under agitation at $4^{\circ} \mathrm{C}$. The immune complexes were pelleted and washed twice with NET buffer. Finally, the beads were resuspended and boiled in denaturating $2 \%$ SDS electrophoretic sample buffer. After electrophoresis on homogeneous $4.5 \%$ gels, the samples were silvernitrate stained (PhastSystem, Pharmacia).

\section{Antigenic cross-reactivities}

The different monoclonal antibodies were assayed using IIF immunocytochemistry and dot-blotting techniques, respectively, against the haemocytes and the plasma of the other shrimp species, $P$. indicus and $P$. vannamei.

\section{RESULTS}

\section{Selection of anti-haemolymph hybridomas and mAb immunofluorescent patterns}

The reactivity of antibodies produced by precloned hybridomas was first analysed by an indirect immunofluorescence assay performed on haemolymph primary cultures. These cultures were directly prepared from haemolymph collected in modified Alsever solution at $\mathrm{pH} 7$ then diluted in SSS, so that haemocytes were adherent to the bottom of plastic microplate wells, were secreting, and that plasma proteins were present. From 440 analysed hybridomas, 72 were shown to be reacting against haemolymph primary cultures. Ten cloned hybridomas were selected and classified according to the mAb immunofluorescent patterns. For this purpose, mAb reactivities were determined, on the one hand, towards cytocentrifuged suspensions of washed and fixed haemocytes, and on the other hand, towards primary cultures of haemocytes previously washed in modified Alsever solution, either at $\mathrm{pH} 7$, where haemocytes recover their ability to adhere and to secrete, or at $\mathrm{pH} 4.6$, where haemocytes are quiescent. Subsequently, it was possible to determine the specificity of mAbs for haemocyte types and/or secreted molecules.

The mAbs were classified into 3 groups (Table 1). Group 1 was composed of 35D6-1A, 40G8-1B, 40G11-1C and 41B12$1 \mathrm{D}$ cloned hybridomas which secrete mAbs reacting similarly against a common antigen present on all the haemocyte types and in plasma (Fig. 1). Group 2 was composed of 40E2-2A and 40E10-2B cloned hybridomas which secrete mAbs reacting against different haemocyte subpopulations (Fig. 2A and B). Group 3 was composed of 41D11-3A, 42C11-3B, 42E8-3C and 44E6-3D cloned hybridomas which produce mAbs strictly reacting with epitopes present only in the plasma (Fig. 3).

\section{Characterisation of haemocytes and related plasma protein using Group 1 mAbs}

At the light microscopy level, it was possible to localize the

Table 1. Immunostaining in indirect immunofluorescence assay (IIFA) of $P$. japonicus haemolymph by specific monoclonal antibodies

\begin{tabular}{|c|c|c|c|c|c|c|c|c|}
\hline \multirow{3}{*}{$\begin{array}{l}\text { Group } \\
1\end{array}$} & \multirow{3}{*}{$\begin{array}{c}\text { MAb } \\
\text { clone no. }\end{array}$} & \multirow{3}{*}{$\begin{array}{c}\begin{array}{c}\mathrm{Ig} \\
\text { isotype }\end{array} \\
\mathrm{IgG} 1\end{array}$} & \multicolumn{2}{|c|}{$\begin{array}{l}\text { IIFA on total } \\
\text { haemolymph }\end{array}$} & \multirow{2}{*}{\multicolumn{2}{|c|}{$\begin{array}{c}\text { AS pH } 7 \text { or } 4.6 \\
\text { washed } \\
\text { haemocyte } \\
\text { primary cultures }(\%)\end{array}$}} & \multirow{2}{*}{\multicolumn{2}{|c|}{$\begin{array}{l}\text { Cytocentrifuged, } \\
\text { AS pH } 4.6 \text { washed } \\
\text { haemocytes }(\%)\end{array}$}} \\
\hline & & & \multirow{2}{*}{$\begin{array}{c}\text { Haemocyte } \\
+++\end{array}$} & \multirow{2}{*}{$\begin{array}{c}\text { Plasma } \\
++\end{array}$} & & & & \\
\hline & & & & & +++ & 100 & +++ & 100 \\
\hline & 40G8-1B & $\operatorname{IgG} 1$ & +++ & ++ & +++ & 100 & +++ & 100 \\
\hline & 40G11-1C & ND & +++ & ++ & +++ & 100 & +++ & 100 \\
\hline & 41B12-1D & IgG1 & +++ & ++ & +++ & 100 & +++ & 100 \\
\hline 2 & $40 \mathrm{E} 2-2 \mathrm{~A}$ & IgG1 & ++ & ++ & ++ & 54 & + & 9 \\
\hline & $40 \mathrm{E} 10-2 \mathrm{~B}$ & $\operatorname{IgG} 2 b$ & ++ & ++ & ++ & 40 & + & 16 \\
\hline 3 & 41D11-3A & $\operatorname{IgG} 1$ & - & ++ & & & & \\
\hline & $42 \mathrm{C} 11-3 \mathrm{~B}$ & IgG1 & - & + & & & & \\
\hline & $42 \mathrm{E} 8-3 \mathrm{C}$ & IgG1 & - & + & & & & \\
\hline & 44E6-3D & IgG1 & - & ++ & & & & \\
\hline
\end{tabular}

$\mathrm{mAb}$ Ig isotypes as indicated.

AS, modified Alsever solution.

+ , positive staining of haemocytes or extracellular compounds (number of + refers to the intensity of staining); -, no staining; ND, not determined. 
epitopes on the cell membranes of all the haemocytes (Fig. 1), whatever the type of haemolymph preparation. Epitopes were also identified in large vesicular inclusions of about $30 \%$ of
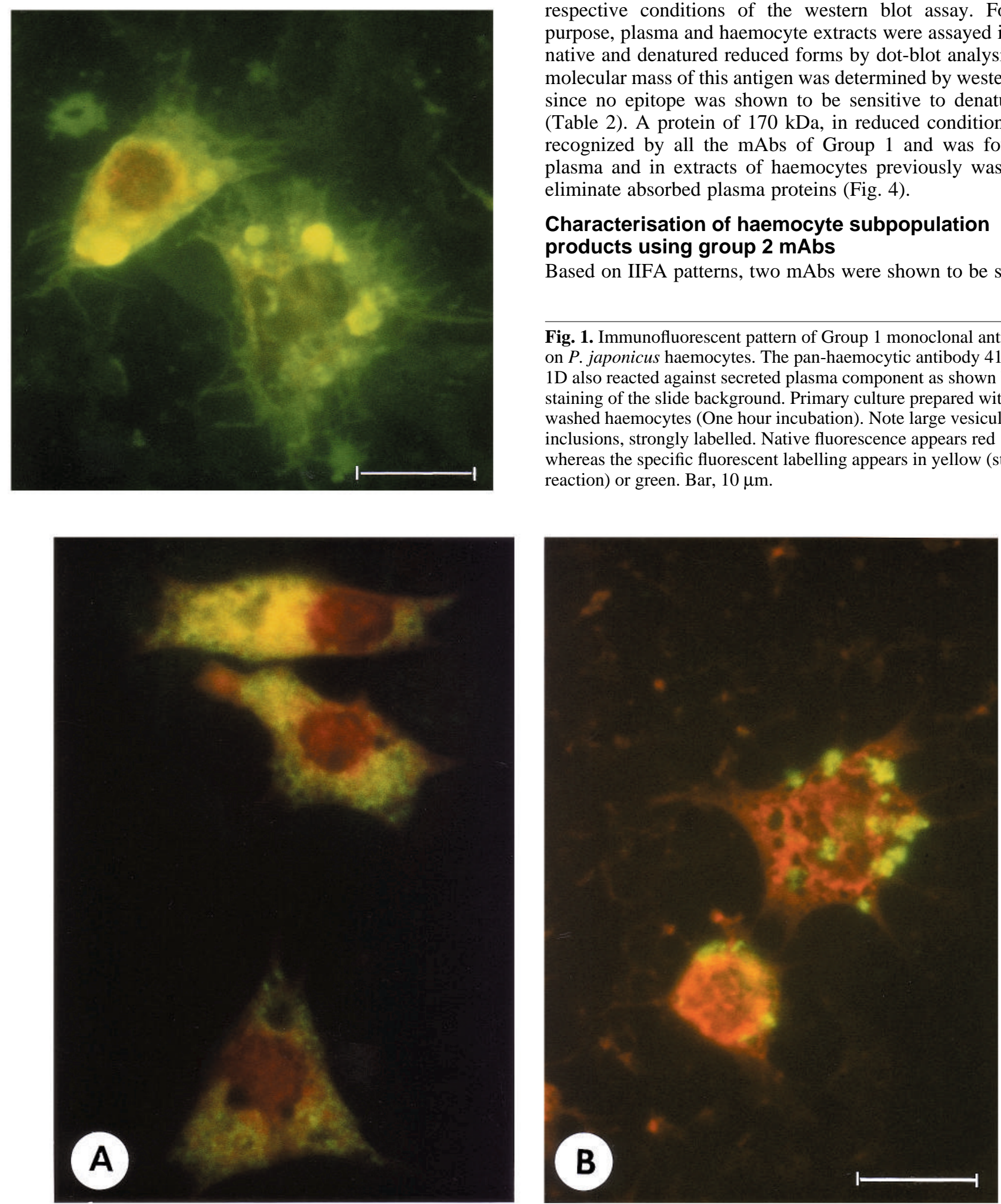

Fig. 2. Immunofluorescent pattern of Group 2 monoclonal antibodies on $P$. japonicus haemocytes. Primary culture of AS pH 7 washed haemocytes: (A) the 40E2-2A antibody reacted with cytoplasmic epitope $(\times 1500)$; (B) the 40E10-2B antibody stained peripheral cytoplasmic vesicles. Bar, $10 \mu \mathrm{m}$. 


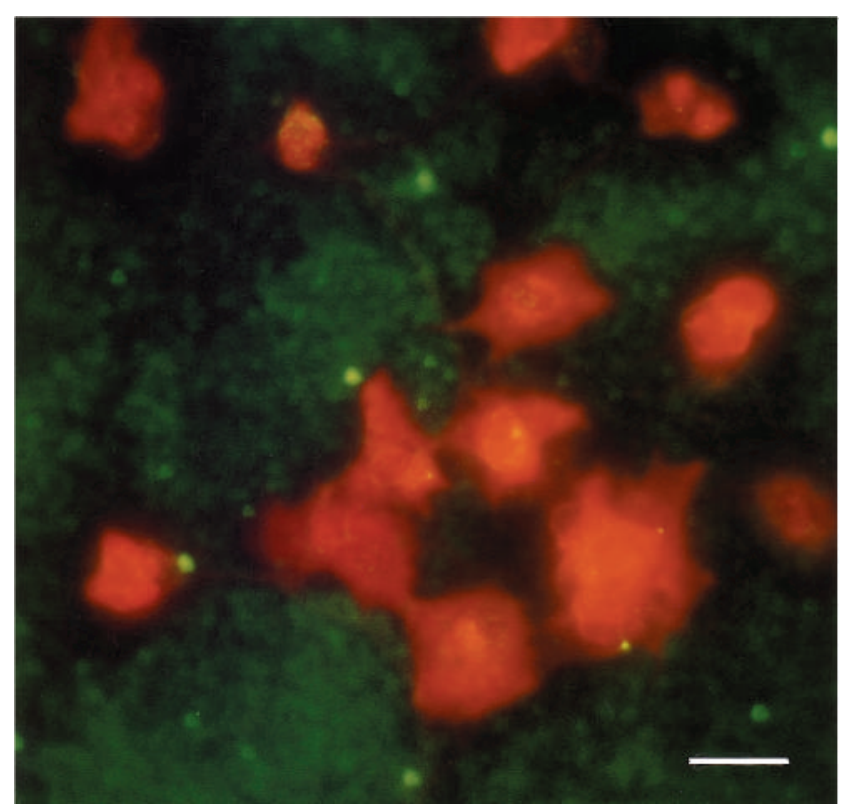

Fig. 3. Reactivity of monoclonal antibody from group 3 against $P$. japonicus haemocyte primary culture prepared with total haemolymph; plasma component was labelled on the slide background when the haemocytes were negative. Bar, $10 \mu \mathrm{m}$.

Table 2. Determination of molecular masses of relevant antigens to the $\mathrm{mAbs}$ from groups 1,2 and 3 by western blot or immunoprecipitation assays

\begin{tabular}{|c|c|c|c|}
\hline \multirow[b]{2}{*}{ Groups } & \multirow[b]{2}{*}{$\mathrm{mAbs}$} & \multicolumn{2}{|c|}{ Molecular mass (kDa) } \\
\hline & & Plasma & Haemocyte extract \\
\hline \multirow[t]{4}{*}{1} & 35D6-1A & $170(\mathrm{Rd})$ & $170(\mathrm{Rd})$ \\
\hline & 4OG8-1B & $170(\mathrm{Rd})$ & $170(\mathrm{Rd})$ \\
\hline & $40 \mathrm{G} 1-1 \mathrm{C}$ & $170(\mathrm{Rd})$ & $170(\mathrm{Rd})$ \\
\hline & $41 \mathrm{~B} 12-1 \mathrm{D}$ & $170(\mathrm{Rd})$ & $170(\mathrm{Rd})$ \\
\hline \multirow[t]{2}{*}{2} & $40 \mathrm{E} 2-2 \mathrm{~A}$ & $142(\mathrm{Rd})$ & ND \\
\hline & $40 \mathrm{E} 10-2 \mathrm{~B}$ & $\begin{array}{l}250,150,66,27 \text { (noRd) } \\
27(\mathrm{Rd})\end{array}$ & $\begin{array}{l}\text { 150, 66, } 27 \text { (noRd) } \\
27(\mathrm{Rd})\end{array}$ \\
\hline \multirow[t]{4}{*}{3} & 41D11-3A & $180(\mathrm{Rd})$ & No relevant antigen \\
\hline & $42 \mathrm{C} 11-3 \mathrm{~B}$ & $180(\mathrm{Rd})$ & in haemocytes \\
\hline & $42 \mathrm{E} 8-3 \mathrm{C}$ & $180(\mathrm{Rd})$ & \\
\hline & 44E6-3D & $75(\mathrm{Rd})$ & \\
\hline
\end{tabular}

(Rd) reduced conditions; (noRd) nonreduced conditions.

for epitopes present in some of the haemocytes and in the medium when haemocytes were cultivated under conditions permitting their secretion activity.

mAb 40E2-2A showed a strong reactivity with cytoplasmic epitopes exhibited by about $54 \%$ of the haemocytes in primary cultures established after washing with Alsever at $\mathrm{pH} 7$ (Fig. $2 \mathrm{~A}$ ), whereas only $9 \%$ of haemocytes were immunorecognized when previously washed at $\mathrm{pH}$ 4.6.

$\mathrm{mAb} 40 \mathrm{E} 10-2 \mathrm{~B}$ recognized, respectively, $40 \%$ and $16 \%$ of the haemocytes previously washed with Alsever at $\mathrm{pH} 7$ and $\mathrm{pH}$ 4.6. The epitope was localized inside cytoplasmic vesicles (Fig. 2B).

It was possible to separate four subpopulations of quiescent haemocytes from $P$. japonicus by isopycnic centrifugation on a discontinuous Percoll density gradient. Each subpopulation was

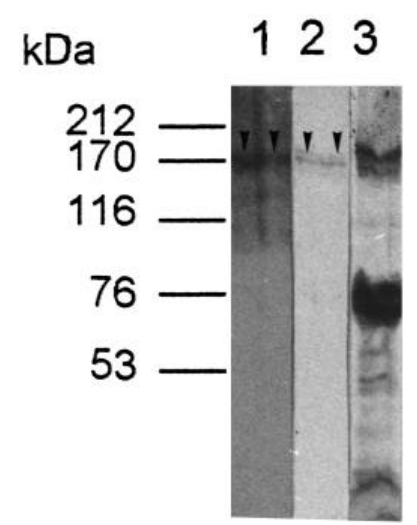

Fig. 4. Western blots of protein extracts prepared from the haemocytes (lane 1) and the plasma (lane 2) of P. japonicus with 41B12-1D mAb; lane 3, crude plasma, silver stained.

Table 3. Antigenic characterisation of $P$. japonicus haemocyte subpopulations separated by isopycnic centrifugation on a discontinuous Percoll gradient with monoclonal antibodies from Group 2, 40E2-2A and 40E10-2B

\begin{tabular}{llcc}
\hline \multirow{2}{*}{ Percoll } & Separated subpopulations & $\begin{array}{c}\text { mAb 40E2-2A } \\
(\%)\end{array}$ & $\begin{array}{c}\text { mAb 40E10-2B } \\
(\%)\end{array}$ \\
\hline $20-30$ & small hyalines & 0 & 100 \\
$30-40$ & hyaline/ semi-granular cells & 0 & 85 \\
$40-50$ & granular/semi-granular cells & 85 & 49 \\
$50-60$ & granular cells & 100 & 0 \\
\multicolumn{2}{c}{ Values are \% of positive haemocytes. } \\
\hline
\end{tabular}

collected and then cytocentrifuged to determine in parallel the morphologic and antigenic types of the haemocytes (Table 3).

\section{Hyaline haemocytes}

A few small hyaline haemocytes with high nucleo-cytoplasmic ratios were collected at the $20-30 \%$ interface of the Percoll gradient. All these cells were recognized by mAb 40E10-2B.

\section{Hyaline and semi-granular haemocytes}

At the 30-40\% interface, we found a mixture of hyaline haemocytes and large haemocytes with dense and basophilic cytoplasm, constituting about $70 \%$ of the cells, which were considered to be semi-granular haemocytes. These separated haemocytes, when reinstated in SSS for primary cultures, displayed quick and intense adherence and spreading. About $85 \%$ of the haemocytes of this interface were recognized by $40 \mathrm{E} 10-2 \mathrm{~B}$ but no haemocytes were labelled by mAb 40E2-2A.

\section{Semi-granular and granular haemocytes}

At the 40-50\% interface, semi-granular haemocytes were obtained, mixed with the major population of granular haemocytes. About $49 \%$ of the haemocytes of this interface were stained by the mAb $40 \mathrm{E} 10-2 \mathrm{~B}$ while $85 \%$ were labelled by the $\mathrm{mAb} 40 \mathrm{E} 2-2 \mathrm{~A}$.

\section{Granular haemocytes}

After isopycnic centrifugation of haemolymph on a Percoll gradient, no semi-granular cells were collected at the $50-60 \%$ 
interface while granular haemocytes strictly banded at the higher densities in the gradient. They were recognizable on cytocentrifuged preparations by their big cytoplasmic granules. Prepared in primary cultures, the granular haemocytes displayed adherence and moderate spreading with formation of pseudopodia emission.

The 50-60\% interface corresponded to a homogeneous population of granular haemocytes on the basis of their morphology as well as antigenic features, since $100 \%$ of the haemocytes were recognized by $40 \mathrm{E} 2-2 \mathrm{~A}$. No staining with $\mathrm{mAb}$ 40E10-2B was obtained.

Both mAbs of Group 2, 40E2-2A and 40E10-2B, reacted only against native proteins, which required that we determine their molecular mass after immunoprecipitation.

As described above, the antigen recognized by mAb 40E22A was regularly distributed in granular cell cytoplasm and was present in the plasma. The molecular mass of the protein immunoprecipitated from the plasma was estimated at 142 $\mathrm{kDa}$, in SDS-PAGE run under reduced conditions (Fig. 5A; Table 2).

According to dot-blot assay, the antigen recognized by $\mathrm{mAb}$ 40E10-2B was present both in plasma and in haemocyte extract. Moreover, it was demonstrated that the protein was secreted by haemocytes since dot-blots were negative for medium from haemocyte-fresh primary cultures and positive for medium from 1 hour-old primary cultures. From haemocyte extract, it was established that the protein recognized by $\mathrm{mAb}$ $40 \mathrm{E} 10$ is present in different forms with molecular masses of $150 \mathrm{kDa}, 66 \mathrm{kDa}$ and $27 \mathrm{kDa}$. From plasma, a supplementary form was identified with a molecular mass of $250 \mathrm{kDa}$ (Fig. 5A). After denaturation, the epitope was found to be associated with the $27 \mathrm{kDa}$ form (Table 2).

\section{Characterisation of plasma proteins by Group 3 mAbs}

All the mAbs of Group 3 were reactive only against native proteins of plasma non represented inside the haemocytes. $\mathrm{mAb} 44 \mathrm{E} 6-3 \mathrm{D}$ recognized a protein of $75 \mathrm{kDa}$ under reducing conditions (Fig. 5A) and cross-reacted against haemocyanin extract.

The three other mAbs immunoprecipitated a protein with an apparent molecular mass of $180 \mathrm{kDa}$ under reduced conditions (Fig. 5B; Table 3).

\section{Cross-reactivity studies against haemolymph of $P$. japonicus, $P$. vannamei and $P$. indicus}

The reactivity of mAbs against haemolymph of $P$. vanname $i$ and $P$. indicus was investigated by IIFA on haemocyte preparations and/or by dot-blotting on plasma, according to the nature of the antigen determined for P. japonicus (Table 4).

All the mAbs of Group 1 reacted against haemocytes of both species, but the immunofluorescent patterns were less intense in comparison to those of $P$. japonicus.
12

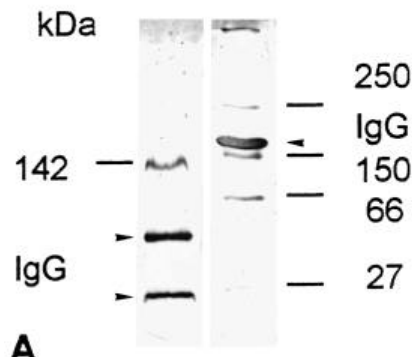

34

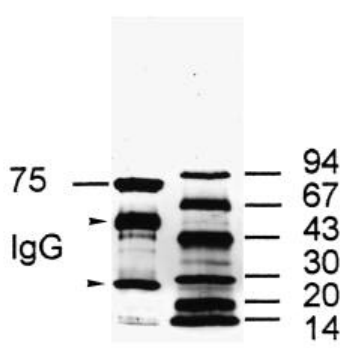

M 1

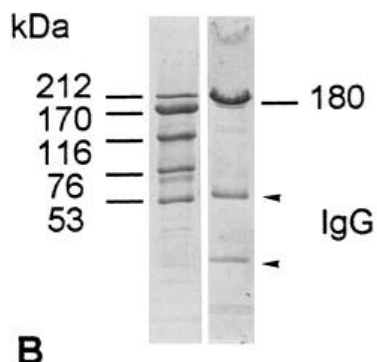

Fig. 5. Electrophoresis patterns of proteins immunoprecipitated by different mAbs. (A) (Phast-gel 4-15\%, Pharmacia) lane 1, plasma protein precipitated with 40E2-2A, reduced conditions; lane 2, plasma protein precipitated with 40E10-2B, unreduced conditions; lane 3, plasma protein precipitated with 44E6-3D, reduced conditions; lane 4, molecular mass markers. (B) (12\% gel) lane M, molecular mass markers; lane 1, plasma protein precipitated with 42E8-3C, reduced conditions. The gels were stained with Coomassie Brilliant Blue.

Table 4. Antigenic relationship between haemocytes and plasma of $P$. japonicus with those of $P$. vannamei and $P$. indicus

\begin{tabular}{|c|c|c|c|c|c|c|c|}
\hline \multirow[b]{2}{*}{ Groups } & \multirow[b]{2}{*}{$\mathrm{mAbs}$} & \multicolumn{2}{|c|}{ P. japonicus } & \multicolumn{2}{|c|}{ P. vannamei } & \multicolumn{2}{|c|}{ P. indicus } \\
\hline & & Haemocytes & Plasma & Haemocytes & Plasma & Haemocytes & Plasma \\
\hline \multirow[t]{4}{*}{1} & 35D6-1A & +++ & ++ & + & ND & + & + \\
\hline & 40G8-1B & +++ & ++ & + & ND & + & + \\
\hline & 40G11-1C & +++ & ++ & + & ND & + & + \\
\hline & 41B12-1 & +++ & ++ & + & ND & +++ & ++ \\
\hline \multirow[t]{2}{*}{2} & $40 \mathrm{E} 2-2 \mathrm{~A}$ & ++ & ++ & ++ & ++ & + & + \\
\hline & $40 \mathrm{E} 10-2 \mathrm{~B}$ & ++ & + & + & ND & ++ & + \\
\hline \multirow[t]{4}{*}{3} & 41D11-3A & - & ++ & - & \pm & - & ND \\
\hline & $42 \mathrm{C} 11-3 \mathrm{~B}$ & - & + & - & \pm & - & + \\
\hline & $42 \mathrm{E} 8-3 \mathrm{C}$ & - & + & - & \pm & - & ND \\
\hline & 44E6-3D & - & ++ & - & - & - & - \\
\hline
\end{tabular}

Reactivity against haemocytes performed by IIFA and reactivity against plasma performed by dot-blot; number of + refers to the intensity of reactivity. ND, not determined. 
Similar results were obtained with mAbs of Group 2 for haemolymph samples from the different shrimp species.

The three mAbs of Group 3, specific for a $180 \mathrm{kDa}$ plasma protein of $P$. japonicus, cross-reacted with plasma of $P$. vannamei, but to a lesser extent. Only mAb 44E6-3D, which recognizes the haemocyanin of $P$. japonicus, was found to be specific.

\section{DISCUSSION}

Although monoclonal antibodies have been proved essential as reagents for characterising immune cells and humoral factors in vertebrates, few studies have produced and used these antibodies in invertebrate immunology. Using hybridoma technology, monoclonal antibodies have been recently prepared for the haemocytes of ascidians (Schlumpberger et al., 1984), annelids (Porchet-Hennere, 1990), gastropods (Yoshino and Granath, 1983; Dikkeboom et al., 1985), marine bivalves (Noël et al., 1991), and insects (Trenczek, 1991; Mullett et al., 1993). These antibodies have been primarily used to recognize haemocyte subpopulations (Noël et al., 1994); they can also permit the study of ontogeny and transformation processes.

This paper, as far we are aware, reports for the first time on the production and the used of monoclonal antibodies to characterize shrimp haemolymph components.

From a technical point of view, it appeared that the use of haemolymph primary cultures prepared in microplate wells was very suitable for screening hybridomas by IIFA. First, this screening led the selection of hybridomas specific for haemocytes and/or plasma components. Moreover, this assay permitted the quick screening of a large number of hybridoma supernatants by taking advantage of the ease of performing all the steps of IIFA in microplates and the observation with microscope at high magnification of the primary cultures after inverting the microplates (Stitz et al., 1988).

The four mAbs of Group 1 are pan-haemocytic markers that may be useful for investigations on hematopoiesis and for histological studies of the immune process because these mAbs recognize any cell irrespective of haemocyte lineage. All these mAbs recognize a $170 \mathrm{kDa}$ protein secreted in the plasma. Recently, a protein with a monomeric form of $190 \mathrm{kDa}$ was purified from the plasma of crayfish (Hergenhahn et al., 1988) and identified as an $\alpha$-macroglobulin. The four mAbs of Group 1 reacted with plasma of other shrimp species. Preliminary results of positive cross-reactions with human and crayfish $\alpha$ macroglobulin (K. Soderhäll, personal communication) suggest that the $170 \mathrm{kDa}$ protein could be the monomeric form of shrimp $\alpha$-macroglobulin. The purification of this molecule will be facilitated by the availability of mAbs, either for affinity chromatography or for following the molecule during the purification process according to any standard technique. It must be noted that $\alpha$-macroglobulin of invertebrates has similarities with the $\mathrm{C} 3$ and $\mathrm{C} 4$ proteins of the complement system (Sottrup-Jensen et al., 1990). In the limule, Limulus polyphe$m u s$, it was shown that $\alpha$-macroglobulin is involved with a $\mathrm{C}$ reactive protein in cytolytic processes (Armstrong et al., 1993).

The shrimp haemocyte types which can be morphologically identified as hyalin and semi-granular cells or as granular cells, correspond to two distinct antigenic populations, respectively, labelled by the mAbs 40E10-2B and 40E2-2A. However, unfortunately, the epitopes are not associated with the cell membranes, and thus these mAbs cannot be used as reagents for specifically purifying the haemocyte subpopulations by immunoaffinity, as is done with vertebrate blood cells (Naume et al., 1991).

Because the antigens recognized by these mAbs are secreted by haemocytes, their purification could also be greatly facilitated for $P$. japonicus, as well as for $P$. vannamei and $P$. indicus since the mAbs cross-reacted.

The hyaline and semi-granular haemocytes, stained by the $\mathrm{mAb} 40 \mathrm{E} 10-2 \mathrm{~B}$, seem to secrete a protein with $27 \mathrm{kDa}$ subunits, which could be organized in polymeric forms or complexed with other proteins. These characteristics may relate the $P$. japonicus $27 \mathrm{kDa}$ protein with lectins purified in other crustacean species. In the balane, Balanus balanoides, a glycoprotein of $330 \mathrm{kDa}$ has been purified and shown to be constituted by sub-units of $70 \mathrm{kDa}$ and $26 \mathrm{kDa}$ (Ogata et al., 1983). A hemagglutinin of $420 \mathrm{kDa}$, which is constituted with 80 and $65 \mathrm{kDa}$ sub-units, has been purified in the crayfish Pacifastacus leniusculus (Kopacek et al., 1993a). In the shrimp $P$. monodon, the monodin is a lectin of $420 \mathrm{kDa}$ constituted with $27 \mathrm{kDa}$ sub-units (Ratanapo and Chulavatnatol, 1990).

The granulocytes are characterised by a protein of $142 \mathrm{kDa}$ which is found in the plasma and also strongly present in the cell cytoplasm as shown by the specific marker, mAb 40E2$2 \mathrm{~A}$. First of all, this mAb will be of great use to study the phylogenetic relationship between granular cells and the other haemocyte types morphologically identified as hyalines and semi-granular cells. The nature of the reactive $142 \mathrm{kDa}$ protein is unknown but the specific mAb will be important in further investigating its role and consequently in the understanding of shrimp granular cell functions.

The mAbs of Group 3 are specific for plasma proteins, which may mean that they are not secreted by haemocytes or that they are antigenically modified after their secretion by haemocytes. The protein recognized by $\mathrm{mAb} 44 \mathrm{E} 6-3 \mathrm{D}$ corresponds to haemocyanin, the respiratory protein which is the major constituent since it represents about $60 \%$ of the haemolymph proteins. From the immunostaining pattern of the haemolymph, it was confirmed that in penaeids the haemocyanin is not present inside the haemocytes, the haemocyanin synthesis site in other decapods having been localised in the hepatopancreas (Gellisen et al., 1991). Beside the haemocyanin, the most abundant haemolymph protein is the coagulogen, also designated as a clotting protein. The three other mAbs from Group 3 probably recognize the shrimp coagulogen, antigenically detected as a $180 \mathrm{kDa}$ monomeric form. This protein is highly represented in shrimp plasma and disappeared from the haemolymph after coagulation as demonstrated by SDS-PAGE (data not shown). In crustaceans, a plasma clotting protein consisting of two disulfide-linked $210 \mathrm{kDa}$ subunits was shown to be involved in clotting reactions (Durliat, 1985). In crayfish $P$. leniuscus, the purified clotting protein monomer has been shown to have a molecular mass of $180 \mathrm{kDa}$ (Kopacek et al., 1993b). The coagulation, by preventing blood loss but also by entrapping pathogenic microoganisms, is considered in crustaceans as an important defense system (Söderhäll and Cerenius, 1992).

In conclusion, a variety of proteins possibly involved in the shrimp immune responses have been identified and detected by specific mAbs. The availability of two mAbs, specific markers 
of distinct haemocyte types morphologically identified as semi-granular and granular haemocytes, will now permit us to develop studies on haemocyte lineage, and also on hemogram composition. Indeed, the antigenic characterisation of hemograms constitutes an essential component in clinical studies of the shrimp immune state and of any modification revealing immunodeficiency. Furthermore, on the one hand, the proteins identified in this study can be purified by immunoaffinity. On the other hand, the mAbs will also be very useful for characterising the corresponding genes by their use as specific probes for screening cDNA libraries cloned in expression vectors.

We are grateful to Dr Song, Department of Zoology, University of Taïwan, for sending $P$. japonicus haemocyanin extract and to Prof. Soderhäll, Department of Physiological Botany, University of Uppsala, Sweden, for testing shrimp mAbs against crayfish haemolymph.

\section{REFERENCES}

Armstrong, P. B., Armstrong, M. T. and Quigley, J. P. (1993). Involvement of $\alpha_{2}$-macroglobulin and C-reactive protein in a complement-like hemolytic system in the arthropod, Limulus polyphemus. Mol. Immunol. 30, 929-934.

Bachère, E., Chagot, D. and Grizel, H. (1988). Separation of Crassostrea gigas haemocytes by density gradient centrifugation and counterflow elutriation. Dev. Comp. Immunol. 12, 549-559.

Dikkeboom, R., Van der Knaap, W. P. W., Maaskant, J. J. and De Jonge, A. J. R. (1985). Different subpopulations of haemocytes in juvenile, adult and Trichobilharzia ocellata infected Lymnaea stagnalis: a characterization using monoclonal antibodies. Zentbl. ParasitKde Abt. I. 71, 815-819.

Durliat, M. (1985). Clotting processes in Crustacea Decapoda. Biol. Rev. 60, 473-498.

French, D., Fischberg, E. Buhl, S. and Scharff, M. D. (1986). The production of more useful monoclonal antibodies. I: Modifications of the basic technology. Immunol. Today 7, 344-346.

Gellisen, G., Hennecke, R. and Spindler, K. D. (1991). The site of synthesis of haemocyanin in the crayfish, Astacus leptodactylus. Experientia 47, 194195.

Hergenhahn, H. G., Hall, M. and Söderhäll, K. (1988). Purification and characterization of an $\alpha$-macroglobulin-like proteinase inhibitor from plasma of the crayfish Pacifastacus leniusculus. Biochem. J. 255, 801-806.

Hose, J. E., Martin, G. G., Nguyen, V. A., Lucas, J. and Rosenstein, T. (1987). Cytochemical features of shrimp haemocytes. Biol. Bull. Lab., Woods Hole 173, 178-187.

Hose, J. E. and Martin, G. G. (1989). Defense functions of granulocytes in the ridgeback prawn Sicyonia ingentis. J. Invert. Pathol. 53, 335-346.

Kölher, G. and Milstein, C. (1975). Continuous cultures of fused cells secreting antibodies of predefined specificity. Nature 256, 495-497.

Kopacek, P., Grubnoffer, L. and Söderhäll, K. (1993a). Isolation and characterization of a hemagglutinin with affinity for lipoplysaccharides from plasma of the crayfish Pacifastacus leniusculus. Dev. Comp. Immunol. 17, 407-418.

Kopacek, P., Hall, M. and Söderhäll, K. (1993b). Characterization of a clotting protein, isolated from plasma of the freshwater crayfish Pacifistacus leniusculus. Eur. J. Biochem. 213, 591-597.

La Peyre, J. F. and Chu, F. L. E. (1990). Blue crab haemocytes: a preliminary study. In Pathology in Marine Science (ed. F. Perkins and T. C. Cheng). Proceedings of the 3rd International Colloquium on Pathology in Marine Aquaculture, Gloucester Point, Virginia (USA), 2-6 October 1988, pp. 533538. Academic Press, San Diego.

Lightner, D. V. (1983). Disease of cultured penaeid shrimp. In CRC Handbook of Mariculture, vol. 1, Crustacean Aquaculture (ed. J. P. McVey), pp. 289320. CRC Press, Boca Raton, Florida.

Mullett, H., Ratcliffe, N. A. and Rowley, A. F. (1993). The generation and characterisation of anti-insect blood cell monoclonal antibodies. J. Cell Sci. 105, 93-100.

Naume, B., Nonstad, U., Steinkjer, B., Funderud, S., Smeland, E. and Espevik, T. (1991). Immunomagnetic isolation of NK and LAK cells. $J$. Immunol. Meth. 136, 1-9.

Noël, D., Boulo, V., Chagot, D., Mialhe, E., Paolucci, F., Clavies, C. Hervaud, E. and Elston, R. (1991). Preparation and characterization of monoclonal antibodies against neoplastic haemocytes of Mytilus edulis (Bivalvia). Dis. Aquat. Org. 10, 51-58.

Noël, D., Pipe, R., Elston, R., Bachère, E. and Mialhe, E. (1994). Antigenic characterization of haemocyte subpopulations in the mussel Mytilus edulis by means of monoclonal antibodies. Marine Biol. 119, 549-556.

Ogata, K., Muramoto, K., Yamazaki, M. and Kamihya, H. (1983). Isolation and characterization of Balanus balanoides agglutinin. Bull. Jap. Soc. Sci. Fish. 49, 1371-1375.

Porchet-Hennere, E. (1990). Co-operation between different coelomocyte populations during the encapsulation response on Nereis diversicolor demonstrated using monoclonal antibodies. J. Invert. Pathol. 56, 353-361.

Ratanapo, S. and Chulavatnatol, M. (1990). Monodin, a new sialic acidspecific lectin from black tiger prawn (Penaeus monodon). Comp. Biochem. Physiol. 97B, 515-520.

Sambrook, J. Fritsch, E. F. and Maniatis, T. (1989). Molecular Cloning: A Laboratory Manual, 2nd edn. Cold Spring Harbor Laboratory Press, NY.

Schlumpberger, J. M., Weissman, I. L. and Scofield, V. L. (1984) Separation and labelling of specific sub-populations of Botryllus blood cells. J. Exp. Zool. 229, 401-411.

Söderhäll, K. and Smith, V. J. (1983). Separation of the haemocyte populations of Carcinus maenas and other marine decapods, and prophenoloxidase distribution. Dev. Comp. Immunol. 7, 229-239.

Söderhäll, K. and Cerenius, L. (1992). Crustacean immunity. Annu. Rev. Fish Dis. 00, 3-23.

Sottrup-Jensen, L., Borth, W., Hall, M., Quigley, J. P. and Armstrong, P. B. (1990). Sequence similarity between $\alpha_{2}$ macroglobulin from the horseshoe crab, Limulus polyphemus, and proteins of the $\alpha_{2}$-macroglobulin family from mammals. Comp. Biochem. Physiol. 96B, 621-625.

Stitz, L., Hengartner, H., Althage, A. and Zinkernagel, R. M. (1988). An easy and rapid method to screen large numbers of antibodies against internal cellular determinants. J. Immunol. Meth. 106, 211-216.

Trenczek, T. (1991). Characterization of insect haemocytes by monoclonal antibodies. Annual Meeting of the American Society of Zoologists Proceedings, 1991, Atlanta, Georgia, USA.

Tsing, A., Arcier, J. M. and Brehélin, M. (1989). Haemocytes of penaeid and palaemonid shrimps: Morphology, cytochemistry and hemograms. J. Invert. Pathol. 53, 64-77.

Vargas-Albores, F., Guzman, M. A. and Ochoa, J. L. (1993). A lipopolysaccharide-binding agglutinin isolated from brown shrimp (Penaeus californiensis Holmes) haemolymph. Comp. Biochem. Physiol. 104B, 407413.

Yoshino, T. P. and Granath, W. O. Jr (1983). Identification of antigenically distinct haemocyte subpopulations in Biomphalaria glabrata (Gasteropoda) using monoclonal antibodies to surface membrane markers. Cell Tiss. Res. 232, 553-564.

(Received 27 June 1994 - Accepted 17 November 1994) 